\title{
PART III.
}

\section{MEDICAL MISCELLANY.}

Reports, Transactions, and Scientific Intelligence.

\section{ROYAI, ACADEMY OF MEDICINE IN IREIAAND.}

\author{
President-Lombe AtThill, M.D., F.R.C.P.I. \\ General Secretary-Joнn B. STory, M.B.. F.R.C.S.I.
}

SECTION OF SURGERY.

President--L. H. Ormsby, P.R.C.S.I.

Sectional Secretary-John Lentaigne, F.R.C.S.I.

Friday, March 6, 1903.

The President in the Chair.

Operative Treatment of Enlarged Prostate.

Sir William Thomson, C.B., read the notes of five cases on which he had operated, following the method described by Mr. Freyer. The patients' ages ranged from 53 to 75 . [This paper will be found at page 321.$]$

\section{The Surgery of the Prostate.}

SIR Thomas Myces read a paper in which he advocated the perineal method of reaching the prostate.

Mr. MitcheLL said the subject was one of great interest. He congratulated Sir W. Thomson on the success of his operation. The great questions for the general practitioner were-(1) When should operation be recommended ? (2) What is the prospect of relief? Undue frequency was due to cystitis, and was the most imperative of all indications. Rapidity of procedure was a most important element in all operations on old men. Every moment an aged patient was kept on an operating table was fraught with danger, and great danger. His own experience and that of the Northern School was in favour of the suprapubic route, but he 
was very favourably impressed with the operation described by Sir Thomas Myles, and would like to have some statistics of cases actually operated on according to his method.

Mr. JoHn Lentaigne was in favour of the suprapubic method; he had no experience yet of the perineal, but the suprapubic was so easy he had been tempted to employ it in each of the few cases he had had an opportunity of operating on. He did not accept the statement that pneumonia after operation was always septic. He had often seen pneumonia of a severe type in other operations where the wound healed aseptically and in the most perfect manner.

SIR T. Myles and SIR W. Thomson replied, and the meeting adjourned.

\section{Friday, April 3, 1903.}

Professor E. H. BennetT in the Chair.

\section{Ulcer Treated by Excision and Grafting.}

Mr. R. ToBin showed a specimen.

Mr. Gondon said that he had operated on several occasions for chronic ulcer of the leg, using Thiersch's grafts. He wished to ask Mr. Tobin if he had followed up his cases for some length of time. He said this because in a case in which he (Mr. Gordon) had operated the ulceration had recurred after the patient had left hospital, and this in spite of the fact that he had kept the patient lying down for three months after the grafting operation.

\section{The Primary Treatment of Fractures by Plaster. of Paris.}

After some preliminary remarks, DR. W. S. HAUGHTON described his method of applying plaster, which was a modification of the old Bavarian splint. The splint was made in two halves, like a pair of stockings, stitched along the back, into which plaster was poured, thus securing homogeneity. Thin oak chips were used to strengthen the splint. The advantages claimed were :(1) Painless treatment, once plaster had set after reduction of deformity; (2) absolute maintenance of reduction, by including joint above and below fracture ; (3) better results in consequence ; (4) in compound fractures, the method diminished discharge from wound, requiring but few dressings ; (5) accessibility for massage or other treatment deemed advisable; (6) much less attention required by surgeon; (7) greater ease in nursing; (8) impossibility of patient doing limb any harm; (9) earlier convalescence 
induced by getting patients up in plaster to walk about; (10) economy of patient's time, and, in hospital cases, of hospital's funds.

Professor BennetT said he was glad Dr. Haughton did not use the roller bandage, as he did not approve it and thought it dangerous. He quoted Helferich's work in support of his argument.

Mr. John Lentaigne said that he had treated a large number of fractures by the immediate application of plaster of Paris during the last twenty years. In many cases he had employed the roller gauze bandage, in the meshes of which the plaster of Paris was held, and he had had none but the best results. Among his cases were more than twenty cases of compound fracture of both bones of the leg. and yet all these cases had been quickly turned into simple fractures and healed in a most satisfactory manner. The method was quite painless. If there were any pain or any evidence of interference with the circulation the splint should at once be cut off, and it then formed two lateral or antero-posterior splints quite homogeneous and in no way resembling a roller bandage is ordinarily used without plaster. The patient should also be kept under observation for forty-eight hours at least, and in applying the splint the extremity of the limb, as the toes in the case of the leg, should be left uncovered so that the circulation could be carefully watched. He had never had an accident from the use of the plaster of Paris, although he had known of very grave accidents in other hands where other methods were employed. In simple fractures his cases were generally allowed to get up in a few days.

Mr. R. L. Swan said he had watched Dr. Haughton's method at work and admired it so much that he had adopted it himself.

\section{Carcinoma of the Larynx.}

Mr. Patrick Dempsey read a paper on this subject. The more common early symptoms were mentioned, and stress was laid on the particular localisation of the growth. Mr. Dempsey quoted statistics showing brilliant results achieved by thyrotomy, when the disease had been diagnosticated at an early stage, and reac! notes of a case of epithelioma of the left vocal cord in which he himself had operated twelve months previously, and in which there was no sign of recurrence.

Mr. R. H. Woons discussed the paper, and Mr. Dempsey replied. 


\title{
SECTION OF PATHOLOGY.
}

\author{
President-E. J. McWeEney, M.D. \\ Sectional Secretary-A. H. WHITE, F.R.C.S.I. \\ Friday, March 27, 1903. \\ The President in the Chair.
}

\section{Adenoma of Breast.}

DR. L. G. GunN exhibited a specimen of a secreting adenoma of the breast, and showed microscopic sections.

The President, Dr. Neville, Professor O'Sullivan, and the SeCretary spoke. Dr. Gunn replied.

\section{Changes in a Rabbit's Kidney due to Experimental Intravenous Injection of Mould Spores.}

The President read a paper on this subject. In the course of immunising rabbits against human blood he had occasionally been compelled to make use of blood that had stood for a considerable time in the refrigerator and had become mouldy. One of the rabbits that had received injections of such blood sickened. and post-mortem one of the kidneys was found enlarged to four times its normal size. On section it was found to be everywhere interpenetrated with. tufts and isolated filaments of fungus mycelium, with here and there what looked like attempts at the formation of sporogenous hyphæ of the Aspergillus type. The histological changes were interesting, and may be summarised as follows:- (1) Disappearance to a large extent of the renal parenchyma and its replacement by a fibro-blastic granulation tissue, containing numerous foreign-body giant-cells of the largest kind, and swarming with cells containing acidophil granulations. of moderate coarseness, whilst others contained granules with a tendency to fix the basic dye--Ehrlich's amphophil or B-group. These cells differed from the eosinophils of human blood in being for the most part mononuclear and fibro-blastic in type. . (2) Presence of fungus hyphæ, sometimes singly, sometimes in groups ef parallel or stellately arranged filaments, and sometimes in short oidium-like segments. The filaments were septate and provided here and there with flask-shaped or globular dilatations. Many of the shorter fungus elements were enclosed in giant-cells. They were devoid of protoplasm, and their highly-refractive cell-wall was distinetly amphophil in reaction. It did not stain selectively by Gram or Ziehl-Nielsen. Where the fungus masses were too 
large to be enclosed in giant-cells they were surrounded by a necrotic zone, rich in broken-down and pyenotic nuclei, very similar to that seen in the precaseous stage of experimental tubereulosis. It was evident that the fungus was not playing the part of a perfectly indifferent foreign-body, but was exercising a necrotising influence on the tissues; yet he had been unable to satisfy himself that any growth had occurred. The filaments appeared to be quite devoid of protoplasm. The occurrenee of swarms of fibro-blastic cells stuffed with coarse acidophil and amphophil granules in the immediate neighbourhood of the fungus-filaments was interesting when viewed in connection with the fact that trichinosis and other helminthiases in the human subject eroked the production of eosinophil cells; he had himself lately examined a case of Bilharzia disease in which most of the pus-cells contained in the urine were of that variety.

The Secretary asked Professor McWeeney if he knew why the fungus lodged in one kidney only?

Professor O'Sullivan would be cautious in assuming that all the cell-granules referred to were eosinophil, and, in addition, asked whether the President had formed any opinion as to the variety of fungus present?

The President, replying to Professor White, said that he did not know why it was that the injected fungus trad lodged in one kidney only. The normal one had been examined and no fungus was found. To Professor O'Sullivan he replied that he quite recognised the distinction between the acidophil and amphophil cell-granules of rodents and the eosinophil granules of human blood. In the absence of perfect sporogenous hyphæ one could not determine the species to which the fungus belonged, but to judge by what looked like an abortive spore-head which he had found, it was most probably an Aspergillus.

\section{Chromogenic Organisms.}

The President showed cultures of a number of these obtained in the course of various bacteriological investigations. Two belonged to the non-liquefying fluorescent group, and were remarkable, one of them for its extremely powerful fluorescent dichroism, the other for the fact that in old cultures the fluorescent green became brown near the surface of the gelatine. Another species he showed was Cladothrix nigra of Rossi Doria, the Cladothrix dichotoma of others. Its pure brown diffusible pigment was very remarkable and accounted, he ventured to think, to some extent, 
for the brown colour of peaty soils which were the natural habitat of this organism. The fluorescent and brown pigments were devoid of typical spectra, but the prodigiosus pigment, of which he handed round a strong solution in amylic alcohol, yielded a typical and beautiful spectrum.

\section{FETAL BLOOD IN MATERNAL TYPHOID FEVER.}

JEHEE (Wien. klin. Woch.) reports the examination of the blood of a seven months' foetus stillborn in the fifth week of its mother's illness with typhoid fever. He found no organisms in it, and the agglutination of typhoid bacilli was much less prompt with it than with the mother's blood. In another case a five months' foetus was born in the third week of the mother's illness with typhoid fever. No bacilli were found in the foetal blood, and no Widal reaction was obtained, though the maternal blood reacted at once. In a case reported by Rouslacroix (La Presse métl.) the mother gave birth to twins almost at term and died of typhoid fever on the eleventh diy of the disease. The mother's blood gave a positive Widal reaction, hut no reaction was given by the blood of the twins.

THE CITY OF MOSCOW PRIZE.

The City of Moscow Prize of 5.000 francs, given at the International Medical Congress to the member of the medical profession who shall be designated laureate by the Congress, has been this year given to M. Metchnikoff, of the Pasteur Institute, Paris. The second prize was given to Signor P. Grassi, of Rome.

\section{OSTEOMYELITIS SIMLLATING TYPHOID FEVYK,}

M. LATARJEr (Lyon médical) reports a case of osteomyelitis which closely simulated typhoid fever. The patient, a man forty years old. was admitted to the Lyons Hospital complaining of a violent headache and great muscular weakness: his temperature gradually reached $104 \cdot 5^{\circ} \mathrm{F}$; he had many watery stools daily; his pulse was small, feeble, dicrotic, and was 104; his tongue was at first broad, flabby, and covered with a soft white fur ; it afterwards became dry, hard and glazed. The effects of the Widal serum test were negative. $\mathrm{IJe}$, in time, rame to complain of a severe pain in the apex of the left shoulder, and over the apex of the spine of the scapula there came a diffused red sweiling, resistant on pressure. An incision made through the deltnid liberated foetid pus and diselosed scapular osteomyelitis. 